\title{
Pattern, process, and function in landscape ecology and catchment hydrology - how can quantitative landscape ecology support predictions in ungauged basins?
}

\author{
B. Schröder \\ University of Potsdam, Institute of Geoecology, Potsdam, Germany \\ Received: 5 May 2006 - Published in Hydrol. Earth Syst. Sci. Discuss.: 29 June 2006 \\ Revised: 20 November 2006 - Accepted: 6 December 2006 - Published: 19 December 2006
}

\begin{abstract}
The understanding of landscape controls on the natural variability of hydrologic processes is an important research question of the PUB (Predictions in Ungauged Basins) initiative. Quantitative landscape ecology, which aims at understanding the relationships of patterns and processes in dynamic heterogeneous landscapes, may greatly contribute to this research effort by assisting the coupling of ecological and hydrological models.

The present paper reviews the currently emerging rapprochement between ecological and hydrological research. It points out some common concepts and future research needs in both areas in terms of pattern, process and function analysis and modelling. Focusing on riverine as well as semi-arid landscapes, the interrelations between ecological and hydrological processes are illustrated. Three complementary examples show how both disciplines can provide valuable information for each other. I close with some visions about promising (landscape) ecological concepts that may help advancing one of the most challenging tasks in catchment hydrology: Predictions in ungauged basins.
\end{abstract}

\section{Introduction}

Landscape ecology and catchment hydrology, both disciplines deal with patterns and processes as well as their interactions and functional implications on a variety of scales (Turner, 2005b; Sivapalan, 2005). Thus, it is reasonable to study the interplay between ecological and hydrological patterns and processes and to seek for mutual possibilities to assist either discipline in dealing with their respective research questions. Each discipline has developed its own theories and methodologies; an interdisciplinary approach assembles the respective benefits and simultaneously provides an alternative viewpoint on the same complex system: landscapes.

Correspondence to: B. Schröder

(boris.schroeder@uni-potsdam.de)
In the following, the terms landscape and catchment are used interchangeably, but the first represents the ecological the latter the hydrological perspective.

In this context, "patterns" are defined as observations exhibiting a spatial or temporal structure that is significantly different from a random process realisation. These patterns contain information on the mechanisms which they emerge from (Grimm et al., 2005). "Processes" are understood as the interactions of different objects in an environment. "Function", however, has different meanings in environmental sciences, denoting either processes, roles, services or the "functioning" of a whole system with perspectives focusing either on the performance of specific objects or on their importance for a specific system (Jax, 2005). I will use the latter definition here.

Based on hierarchy theory and further developments, landscapes have been referred to as complex adaptive systems, in which patterns at higher levels emerge from localised interactions at lower levels (Levin, 1998). Complexity arises from the interplay between intraspecific and interspecific biotic interactions and from different abiotic constraints and interacting driving forces and disturbances - all of them acting on a hierarchy of spatial and temporal scales. Understanding of these complex interactions, identifying the underlying driving forces and the reliable prediction of resulting system's responses are the main objectives of environmental research. In this context, a typical area of landscape ecological research is the analysis of the effect of spatiotemporal resource distribution on the persistence, distribution and richness of species (e.g. Wiens, 2002a). Catchment hydrology typically focuses on the understanding of the effect of the spatiotemporal distribution of soil and topographical properties on the soil moisture pattern or on the runoff response (e.g. Wilson et al., 2005). Both objects of interest, species, soil moisture, and runoff, play important roles in specific landscape functions as for instance biomass production, nutrient cycling, or groundwater recharge.

Published by Copernicus GmbH on behalf of the European Geosciences Union. 
Thanks to the substantial methodological advances in the area of observation (e.g. remote sensing), analysis (e.g. geographical information systems, spatial statistics), and modelling (e.g. digital terrain modelling, physically-based simulation modelling), the availability of computer power and the development of theories no longer neglecting space (Kareiva, 1994), ecologists as well as hydrologists turned to a spatial paradigm - considering spatial and spatiotemporal patterns, relationships, and processes (Grayson and Blöschl, 2000a).

Accordingly, recent scientific questions in landscape ecology and hydrology focus on the interactions of patterns and processes and their functional implications. Not only catchment hydrologists but also landscape ecologists apply modelling approaches to tackle this task. Based on their respective theoretical backgrounds (cf. Beven, 2002; Reggiani and Schellekens, 2003; Wiens, 2002b; Levin, 1992), phenomenological models (sensu Bolker, 2006) are used for pattern descriptions, whereas mechanistic models are used for process description and pattern generation in an adaptive cycle of inference - i.e. formulating, testing, and rejecting hypotheses on the basis of comparisons between observed and simulated patterns (Holling and Allen, 2002). Recent developments in ecological and hydrological modelling emphasize the use of multiple patterns providing insight into different aspects of the studied system for model building and calibration (Grimm et al., 2005; Wiegand et al., 2004; Beven, 2006).

The present paper reviews the currently emerging rapprochement between ecological and hydrological research. It points out some common concepts and future research needs in both areas in terms of pattern, process and function analysis and modelling. After presenting some already realised or realisable collaborations, I close with some visions regarding promising concepts from (landscape) ecology that may help advancing one of the most challenging tasks in catchment hydrology: Predictions in ungauged basins (PUB).

\section{Interplay between ecology and hydrology}

The interplay between ecological and hydrological research commences on different levels and scales. Several studies present a growing number of emerging rapprochements between ecological and hydrological research in different fields, such as ecohydrology (cf. these special issues: Wassen and Grootjans, 1996; Wilcox and Newman, 2005; Gurnell et al., 2000; Zalewski, 2002; Baird et al., 2004) or riverine landscape ecology (Stanford, 1998; Tockner et al., 2002; Ward et al., 2002b; Poole, 2002). Today, ecohydrology emerges as a new interdisciplinary field or even paradigm (Hannah et al., 2004; Bond, 2003; Rodriguez-Iturbe and Porporato, 2004).
2.1 Landscape ecological concepts - applicable to catchment hydrology?

Landscape ecologists describe heterogeneity in landscapes in terms of two concepts: patch-matrix and gradients (e.g. Turner et al., 2001; Wagner and Fortin, 2005). The first relates to island-biogeography (MacArthur and Wilson, 1967) and metapopulation theory (Hanski and Gilpin, 1997), the second to niche theory (Hutchinson, 1957) and community ecology (e.g. Austin, 1985). Patches are defined depending on the scale and the research question (Addicott et al., 1987); patches differ in patch quality, their boundaries affect flows of energy, material, and species; patch context matters, and composition and configuration of patches affect local and regional processes (Wiens, 2002a).

Wu and Levin (1997) describe ecological systems as hierarchical dynamic mosaics of patches (cf. Poole et al., 2004). Local patch dynamics can constitute shifting mosaics - socalled mosaic cycles - if the patches exhibit similar but outof-phase dynamics (e.g. Olff et al., 1999; Remmert, 1991; Watt, 1947). Unsurprisingly, this kind of shifting landscape mosaics is also found in hydrologically controlled systems (Bornette and Amoros, 1996; Malard et al., 1999; Latterell et al., 2006).

Riverine landscape ecology continues the success story of the landscape ecological framework focusing on the interface of terrestrial and aquatic systems (Ward et al., 2002a; Tockner et al., 2002). According to Wiens (2002a), all relevant concepts derived from landscape ecological theory can be exemplified within riverine landscapes - and vice versa, riverine systems provide good opportunities to test this theory.

Since organisms determine the structure and functioning of landscapes (Covich et al., 2004), many landscape ecologists follow an organisms-centred perspective (e.g. Wiens et al., 1993). One aim of quantitative landscape ecology is the understanding of species-habitat relationships and the prediction of the spatio-temporal species distribution by means of species distribution modelling (Guisan and Thuiller, 2005). Species habitat selection is controlled by environmental resources on a hierarchy of spatial and temporal scales (Mackey and Lindenmayer, 2001). On small scales, selective forces are mainly biotic interactions such as predation and competition; on larger scales, the abiotic environment and related disturbance regimes are more important (Biggs et al., 2005). Keddy (1992) describes landscapes as a hierarchy of environmental filters (see also Diaz et al., 1998; Lavorel and Garnier, 2002): to join a local community, species in a regional species pool must possess appropriate functional attributes (i.e. species traits) to pass through the nested filters. Only those species build the community that is encountered in a given landscape, whose habitat requirements match the abiotic and biotic habitat conditions. This concept was originally proposed to assembly rules in vege- 
tation community ecology but it is just as well applicable in riverine landscapes (Poff, 1997; Statzner et al., 2004).

A common landscape ecological framework illustrated in the top half of Fig. 1 (modified after Wiens, 2002a) is applied to catchment hydrology (bottom half) to pinpoint their common ground. According to Wiens (2002a), the landscape pattern is derived from the kinds of elements it contains (i.e. composition) and their spatial configuration, both reflecting heterogeneity in patch quality and patch context. The interplay between the landscape pattern and the ways in which organisms respond to that pattern (as determined by the organisms' ecological, morphological, behavioural, and life-history traits) affects spatially dependent landscape processes. The interrelationship between landscape pattern and processes produces spatial dependencies in ecological patterns, processes and functions (as for instance connectivity), which are again mediated by organism traits (e.g. dispersal capabilities).

Analogue to landscape ecology, the description of spatial patterns is a prerequisite to improve the understanding of hydrological processes in catchment hydrology and thus to yield better predictions for the right reasons (Grayson and Blöschl, 2000b). Structure and texture may be seen in the context of patches (for instance zones of surface saturation, macropores) and matrix, reflecting heterogeneity in soil and terrain properties. Again, composition and configuration of structural elements determine the catchment pattern. This pattern is related to terrain, soil, biota and their respective interactions (Sivapalan, 2005), which can be described as geomorphologic, edaphic and ecological subbasin traits that control spatially dependent catchment processes and functions (Fig. 1). Composition/configuration (Turner, 1989) and structure/texture (Vogel and Roth, 2003) are scale-dependent concepts and have to be characterised depending on the scale considered.

2.2 Riverine landscapes - examples of the interaction between ecological and hydrological processes

There is a multitude of examples showing the effects of hydrologic patterns and processes on ecological features, and riverine landscapes shall provide the first examples here. For instance, Naiman and Decamps (1997) as well as Ward et al. (2002b) review the ecological diversity of riparian zones. Here, the dynamic environment supports a variety of life-history strategies and organisms adapted to disturbance regimes over broad temporal and spatial scales (Lytle and Poff, 2004). These dynamics result in shifting landscape mosaics, which many riverine species rely on and have become adapted to (Ward and Tockner, 2001). As Robinson et al. (2002) point out, the migration of many species is tightly coupled to the temporal and spatial dynamics of the shifting landscape mosaic. Tabacchi et al. (1998) review how vegetation dynamics are influenced by the hydrological disturbance regime and how in turn, vegetation productivity and diversity

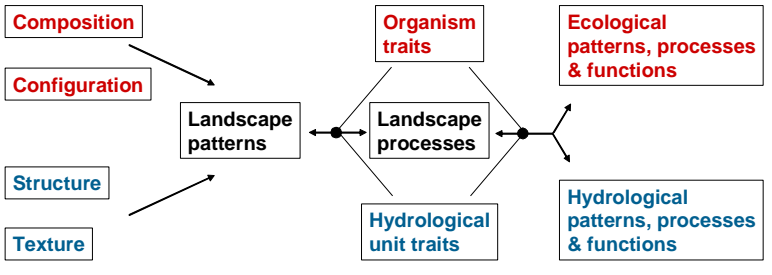

Fig. 1. A common landscape ecological framework (top half after Wiens, 2002a) and its analogous application to catchment hydrology.

influence riverine biogeochemical and geomorphologic processes (cf. Burt and Pinay, 2005; Gurnell et al., 2001).

Likewise, literature is full of examples showing the effects of ecological patterns and processes on hydrological features. As an example, Tabacchi et al. (2000) review the impacts of riparian vegetation on hydrological processes, i.e.: (i) the control of runoff by the physical impact of living and dead plants on hydraulics, (ii) the impact of plant physiology on water uptake, storage and return to the atmosphere, and (iii) the impact of riparian vegetation functioning on water quality. Other prominent examples refer to so-called ecosystem engineers, i.e. species that are able to change environmental conditions (Jones et al., 1994). A famous example is dambuilding beaver, Castor canadensis, whose dams have dramatic effects on community structure and ecosystem functioning of entire catchments (Naiman et al., 1988; Wright et al., 2002). Another example for ecosystem engineering in riverine landscapes is studied by Wharton et al. (2006): Instream macrophytes and associated suspension-feeding invertebrates that modify flow velocities, alter flow patterns and promote trapping of fine sediments in the lowland catchments of British "chalk rivers".

\subsection{Ecohydrological research of arid and semi-arid land- scapes}

Arid and semi-arid landscapes shall provide the second set of examples on the effects of hydrologic patterns and processes on ecological features and vice versa. Since water is the most limiting resource to biological activity in these environments, ecological processes are vitally linked to catchment hydrology (Loik et al., 2004; Williams et al., 2006). Ecohydrological research in these regions focuses on the integration of ecology, hydrology and geomorphology and the related formation of self-organised patterns.

So, for instance, Huxman et al. (2005) present a conceptual model that highlights important ecological and hydrological interactions in semi-arid landscapes. They illustrate how changes in vegetation structure (i.e. woody plant encroachment) influence groundwater recharge and how the ratio of plant transpiration to total evapotranspiration - repre- 
senting the relative contribution of ecological processes to hydrological fluxes - can affect productivity. In a series of papers, Rodriguez-Iturbe et al. (2001), Laio et al. (2001b,a) and Porporato et al. (2001) model the interplay between climate, soil and vegetation for soil moisture dynamics and water balance. Due to the pulsed resource supply in arid and semi-arid landscapes (Chesson et al., 2004; Schwinning and Sala, 2004), not only spatial water partitioning is important (Ehleringer et al., 1991) but also partitioning over time (Schwinning et al., 2004).

As shown in numerous studies, vegetation patterns play an important role in determining the location of runoff and sediment source and sink areas in arid and semi-arid regions (Cammeraat and Imeson, 1999; Ludwig et al., 2005; Valentin et al., 1999; Wilcox et al., 2003). These patterns are functionally related to hydrologic processes through their effect on soil moisture, runoff and evapotranspiration; and to geomorphologic processes through their role on determining the spatial distribution of erosion-deposition areas (Puigdefabregas, 2005; Boer and Puigdefabregas, 2005; Imeson and Prinsen, 2004). Infiltration is enhanced under vegetated patches due to improved soil aggregation and macroporosity related to biological activity (Ludwig et al., 2005). Thus the spatial redistribution of flows and material is regulated by both topography and vegetation and is strongly influenced by the interaction between vegetated and bare patches that is determined by their spatial connectivity (Imeson and Prinsen, 2004). So, the self-organised vegetation pattern formation in semi-arid and arid landscapes can be explained by the positive feedback between plant density and water infiltration as well as the redistribution of runoff water (HilleRisLambers et al., 2001).

\subsection{Identification of common concepts and common needs}

\subsubsection{Identification of common concepts}

Landscape ecology and catchment hydrology exhibit a set of common notions and concepts. The ecological and hydrological view of landscapes emphasizes the importance of spatial structure and heterogeneity (Turner, 1989; Grayson et al., 1997; Schulz et al., 2006).

Although spatial structure is a core concept for both disciplines, landscape ecologists - at least in their beginning - and hydrologists apply different approaches to characterise it: landscape metrics in contrast to spatial statistics and geostatistics. Landscape metrics (or landscape pattern indices) focus on discrete spatial variation (O'Neill et al., 1988; Gustafson, 1998). Unfortunately, the distribution, expected values and variances of many landscape metrics are not known. Therefore, statistical comparisons between multiple observations of an index are at least challenging (but see Remmel and Csillag, 2003). In contrast, spatial statistics and geostatistics mainly focus on continuous spatial variation (e.g. Fortin and Dale, 2005). Due to the fact that a) many variables of ecological interest are continuous and represented as gradients, and b) these methods allow for statistical inference, hypothesis testing, spatial extrapolation, and characterisation of spatial autocorrelation, spatial statistics and geostatistics are increasingly applied in quantitative landscape ecology.

Spatial heterogeneity is expressed as gradients or as patchiness and is considered as being scale-dependent (Klemes, 1983; Blöschl and Sivapalan, 1995; Delcourt and Delcourt, 1988). A scale-dependent approach is pivotal since processes that are important at one scale are not necessarily important at other scales (Sivapalan et al., 2003a): Dominant processes change with changing scales (Grayson and Blöschl, 2000b). This approach implies the notion of hierarchy to understand complexity (Sivapalan, 2005; Wu, 1999; Urban et al., 1987).

Another common concept currently gaining increased attention is connectivity. This means the functional connectedness between landscape elements like habitat patches inhabited by spatially structured populations (Söndgerath and Schröder, 2002; Cottenie and De Meester, 2003) or between catchments elements (Pringle, 2003; Ocampo et al., 2006) such as hydrological flow paths in rivers (Amoros and Bornette, 2002) or spatially-evolving source areas in drainage lines (Western et al., 2001). Connectivity focuses on horizontal processes and thus yields a viewpoint that is qualitatively different from patch-centred approaches focusing mainly on vertical processes (Burt and Pinay, 2005). Urban and Keitt (2001) propose a graph-theoretic perspective to deal with landscape connectivity.

Connectivity - or its counterpart fragmentation - is strongly related to the question of extinction thresholds in the context of metapopulations (i.e. "populations" of subpopulations Bascompte and Sole, 1996; Keitt et al., 1997). If connectivity falls below a critical threshold, dispersal between remaining habitats does not suffice in balancing local extinctions (Keymer et al., 2000; Ovaskainen et al., 2002). Landscape ecologists apply percolation theory (Stauffer and Aharony, 1991) and neutral landscape models (Gardner et al., 1987) to determine the relative importance of landscape components and their configuration on the distribution of populations (With et al., 1997). Extinction thresholds are one striking example for critical thresholds that have drawn the attention of ecologists (e.g. With and Crist, 1995) and hydrologists (e.g. Cammeraat, 2004; Zehe et al., 2005). Critical thresholds - meaning that small environmental perturbations can produce large, discontinuous and irreversible changes in ecosystems, landscapes, and communities - are strongly related to nonlinear dynamics and multiple stable states (May, 1977; Rietkerk and van de Koppel, 1997; Groffman et al., 2006) and pose a challenge to prediction and management (Rietkerk et al., 2004b).

\subsubsection{Identification of common needs}

Turner (2005a) suggests that both approaches to charac- 
terise spatial structure, landscape metrics and spatial statistics, should be unified under a general framework for the representation of spatial heterogeneity. This framework should also encompass graph theoretical approaches as proposed by Cantwell and Forman (1993), Reynolds and Wu (1999) and Urban and Keitt (2001) to represent connectivity-related issues.

Furthermore, there is a common need to find appropriate scaling methods and a theory of scaling (Urban, 2005; Sivapalan, 2003). The concept that "scale matters" is common ground in environmental sciences. Regarding scaling laws and related topics recent years have seen considerable advances in ecology (e.g. Ritchie and Olff, 1999; Milne et al., 2002; Keitt and Urban, 2005; Southwood et al., 2006) as well as hydrology (e.g. Western et al., 2002; Vogel and Roth, 2003) and geomorphology (e.g. Dodds and Rothman, 2000). But according to Wiens (1999), we still have only fragments of a theory of scaling.

A model-based analysis of pattern-process interactions strongly relies upon process-based simulation models providing the opportunity to carry out virtual experiments (Peck, 2004; Weiler and McDonnell, 2004). Therefore, pattern comparison is a pivotal step to decide how well individual processes are represented (Grayson and Blöschl, 2000a). Moreover, the comparison and resulting discrepancies can provide suggestions for modifications of the model structure and parameters (Grayson and Blöschl, 2000b). Thus, the identification of a set of quantitative, robust, and reproducible methods for the analysis of spatiotemporal patterns that go beyond classical, non-spatial approaches represents a major future challenge for model-based analysis of patternprocess interactions in landscape ecology and catchment hydrology (Schröder and Seppelt, 2006). Promising approaches comprise point pattern analysis (e.g. Jeltsch et al., 1999), spatiotemporal application of entropy (Parrott, 2005; Lischke, 2005) and wavelet transforms (e.g. Milne et al., 2005).

Due to the reciprocal effects of abiotic and biotic patterns and processes, disciplinary approaches can only yield limited insights. We need interdisciplinary studies and complementary perspectives to facilitate a deeper understanding of the multifaceted and complex interactions between abiotic and biotic patterns and processes acting on multiple temporal and spatial scales. This may prevent us from inventing the wheel again and again. The following section gives examples on how hydrological models help to improve landscape ecological predictions and how landscape ecological models support hydrological modelling.

\section{Examples}

\subsection{Example I - Hydrology helps landscape ecology}

Species distribution models (SDMs) are a well-established method to predict the spatial distribution of species based on

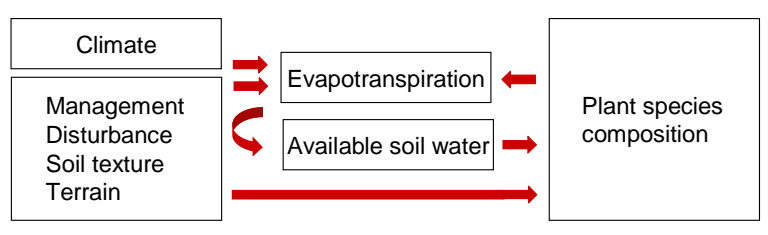

Fig. 2. In the landscape model presented by Rudner et al. (2007), plant species composition is affected by i) management and related disturbance, ii) static soil and terrain parameters as well as iii) plant available soil moisture. The latter is driven by climate and evapotranspiration which itself depends on plant cover.

environmental predictors (Guisan and Zimmermann, 2000; Guisan and Thuiller, 2005). Since hydrologic conditions are important niche parameters controlling the occurrence of many species (Silvertown et al., 1999), considering hydrologic parameters as environmental predictors finds wide application in landscape ecology: De Swart et al. (1994) and Leyer (2005), for instance, predict plant species responses to water level fluctuations. Similarly, Zinko et al. (2005) predict plant species richness basing on a topography-based groundwater flow index. Applying a comparable approach, Peppler-Lisbach and Schröder (2004) predict the community composition of mat grass communities on a biogeographic scale considering soil moisture, nutrient conditions, management and climate.

More advanced approaches try to predict species compositions considering the dynamics of predictors and related feedbacks. As an example, Rudner et al. (2007) apply an integrated landscape model to investigate the ecological consequences and costs of different management regimes in $21 \mathrm{~km}^{2}$ semi-natural grasslands in southern Germany. The model relates topographic and edaphic conditions, dynamics of soil water, evapotranspiration and disturbance caused by management to species composition (see Fig. 2). The dynamics of abiotic site conditions - following comparatively simple approaches described in DVWK (1996) and Allen et al. (1998) - and of disturbances (i.e. management practices) were modelled as driving factors for plant species distribution of more than 50 plant species in a spatially explicit way (see Schröder et al., 2004, for validation results of abiotic models). Model performance of the underlying logistic regression SDMs is considerably high in terms of model calibration (Nagelkerke's $R^{2}$ mean: $0.42 \pm 0.17 \mathrm{sd}$, min: 0.19 , max: 0.89) and AUC, i.e. the area under a receiver-operating characteristic curve depicting model discrimination (mean $0.86 \pm 0.07 \mathrm{sd}$, min: 0.73 , max: 0.99). Both criteria were calculated after internal model validation via bootstrapping using R 2.2.0 (http://www.r-project.org) with packages Hmisc and Design (Harrell, 2001).

For 15 out of 50 plant species, the average amount of plant available water in April or June was considered as a significant predictor variable in the underlying SDMs. Figure 3 


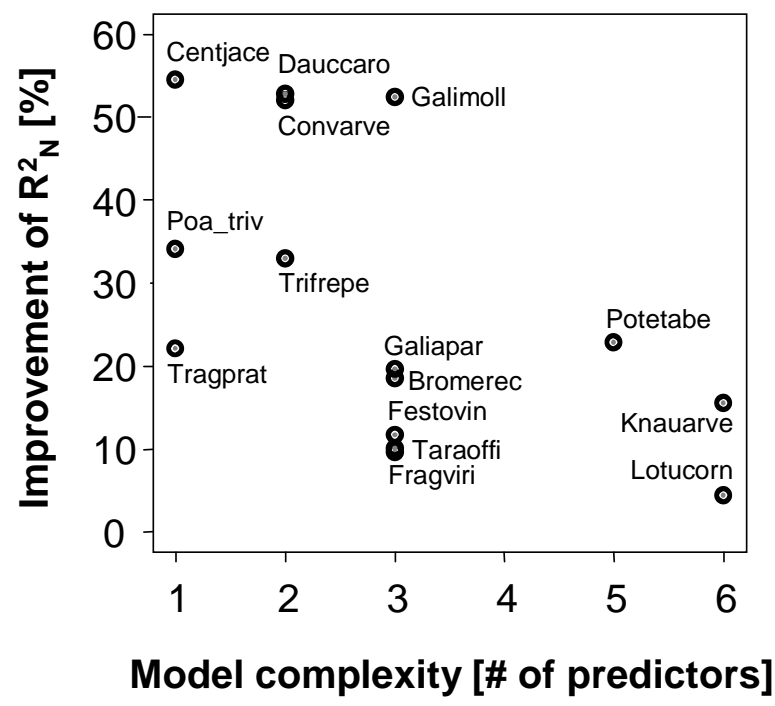

Fig. 3. Improvement of model performance in terms of Nagelkerke's $R^{2}$ related to considering mean content of plant available water in a set of plant distribution models. Model complexity depicts the number of additional predictor variables considered in the logistic regression models. The species codes refer to Centaurea jacea, Poa trivialis, Tragopodon pratensis, Daucus carota, Convolvulus arvensis, Trifolium repens, Galium mollugo, Galium aparine, Bromus erectus, Festuca ovina, Taraxacum officinalis, Fragaria viridis, Potentilla tabernaemontani, Knautia arvensis, and Lotus corniculatus.

shows the significant improvement of model performance including this predictor compared to models neglecting it in terms of Nagelkerke's $R^{2}$ depending on model complexity (i.e. the number of additional predictors variables).

As Fig. 3 shows, an additional consideration of hydrologic conditions, as represented by the amount of plant available water, yields considerable improvements in predicting the distribution of plant species. The improvement is higher for simpler models. A model comparison basing on Akaike's information criterion (AIC) reveals that the improvement is higher than expected due to the increasing model complexity. This simple example shows the significance of hydrological information in predicting species or species richness distribution.

\subsection{Example II - landscape ecology helps hydrology}

The other way round, hydrologists can learn to interpret ecological patterns and use them either as input data or as additional information for model validation or measurement network design. Vegetation integrates over conditions prevalent over large time scales. Ecologists have developed some wellestablished approaches to relate species occurrence and composition to abiotic factors. Accordingly, the spatial pattern of vegetation can be used for hydrological purposes such as the validation of the likelihood of spatial soil moisture patterns or flood frequencies. An example for such an approach are Ellenberg's (1992) indicator values that relate plant species response to light, temperature, continentality, soil moisture, soil $\mathrm{pH}$, soil fertility, and salinity on an ordinal scale integrating over life-span growth conditions (cf. Ellenberg, 1988). Such indicators values yield an operational knowledge of vegetation response to site conditions, which still draws considerable attention in the ecological literature (Schaffers and Sykora, 2000; Diekmann, 2003; Ertsen et al., 1998) as well as hydro-ecological applications (Waldenmeyer, 2002). Hill et al. (2000) suggests a method to extend these indicator values to new areas; Schmidtlein (2005) presents an approach to obtain maps of Ellenberg indicator values for soil moisture, soil $\mathrm{pH}$ and soil fertility by means of hyperspectral imaging.

Using more advanced statistical methods like generalised linear models (GLM) or generalised additive models (GAM), "eco-hydrological" species distribution models (SDMs) relate species presence/absence data to environmental conditions by modelling relevant aspects of realised species niches (Olde Veterink and Wassen, 1997; Bio et al., 2002). This kind of models provides complementary ecological patterns that can support catchment hydrologists in identifying different properties of catchment behaviour. Applying a similar approach, Wierda et al. (1997) use plant species as indicators of the groundwater regime. Similarly, Lookingbill et al. (2004) use plant species for the prediction of soil moisture levels. Invertebrates show a much faster response to changes in environmental conditions due to their short life cycle and high mobility. Bonn and Schröder (2001) model the shortterm micro-spatial distribution of carabid beetles depending on temporary waters together with related soil conditions and vegetation structure. In combination or alternatively, multivariate ordination techniques can be applied to analyse entire biotic communities (Rosales et al., 2001; Weigel et al., 2003). It is noteworthy that hydrological model predictions should not be used as predictors in habitat models if simultaneously resulting predicted ecological patterns are used for calibrating hydrological models: one would be trapped in vicious cycles.

Since predictive species distribution models quantitatively describe ecological patterns, they have the potential to improve hydrological model predictions. In analogy to pedotransfer functions (e.g. Vereecken, 1995), they can be interpreted as habitat transfer functions estimating the distribution of species or species groups based on habitat selection theory using simple landscape properties. For the benefit of hydrological applications, they can be used to predict the spatial distribution of a) environmental engineers driving hydrological processes and affecting hydrological functions or b) bioindicators for validation of catchment models.

Evident examples of ecological engineers that affect hydrological (and biogeochemical and geomorphologic) functions are earthworms. They significantly influence - among 
others - hydraulic properties (Smettem, 1992), infiltration (Edwards et al., 1989; Shipitalo and Butt, 1999), water movement (Shipitalo et al., 2000) by modulating soil physical and chemical properties and forming long-lasting microstructures. Earthworm burrows result in macroporosity modifying soil infiltrability and preferential flow and therefore affecting runoff generation as well as transport and degradation of substances (Zehe and Flühler, 2001; Ludwig et al., 2005; Bolduan and Zehe, 2006). Due to further feedbacks regarding nutrient dynamics (Dominguez et al., 2004; Le Bayon and Binet, 2006) and plant growth (Milcu et al., 2006), earthworms play a pivotal role in ecosystem functioning (Lavelle et al., 1997; Jouquet et al., 2006). Obviously, predicting the diversity and spatial distribution of these organisms in a catchment based on soil ecological knowledge and available data on land use, topography, and soil properties would yield a valuable input for catchment models or a pivotal complement for measurement network design (Zehe et al., 2001). Unfortunately, species distribution modelling for soil macrofauna is still in its infancy (but see e.g. Jimenez et al., 2001; Decaëns and Rossi, 2001, who predict distribution of earthworms by geostatistical means).

3.3 Example III - Integrated ecohydrological processbased models

So far, the examples given above mainly focus on one-way exchanges of information between the disciplines: Hydrological information improving ecological models and viceversa. The integrated landscape model presented in example I considers feedbacks between hydrological and ecological components, but only the abiotic model part is processbased whereas the SDMs that predict the biotic response are statistical models. Personally, I expect the most valuable progress from integrated process-based models combining cutting-edge ecological and hydrological modelling efforts (cf. Tietjen and Jeltsch, 2006). Some recent achievements in the field of ecohydrological modelling deal with the topic of self-organised vegetation pattern formation that can be observed on homogeneous soils without an underlying patchiness in environmental conditions. Integrated process-based models were set up for different ecological systems, for instance semi-arid grazing systems (HilleRisLambers et al., 2001), arid ecosystems (Rietkerk et al., 2002) or bogs (Rietkerk et al., 2004a) leading to a more general understanding of this fascinating example of self-organisation in ecosystems which is strongly connected to questions of resilience, multiple stable states and catastrophic shifts (van de Koppel and Rietkerk, 2004; Rietkerk et al., 2004b).

The above-mentioned study of Rietkerk et al. (2002) may serve as an example for an integrated ecohydrological process-based model. The authors present a mechanistic, spatially explicit, process-based model to explain a striking vegetation pattern observed in arid regions: a two-phase mosaic of vegetated patches and bare soil which scale and shape depends on rainfall and slope (e.g. Valentin et al., 1999). The model considers the spatiotemporal dynamics of surface water, soil water, and plant density by a set of three coupled partial differential equations for these state variables. Results show that the vegetation patterning is caused by one single mechanism: differences in infiltration between vegetated ground (with faster infiltration) and bare soil that lead to a net displacement of surface water to vegetated patches. In a further study, van de Koppel et al. (2002) extend this model to explain catastrophic shifts in semi-arid grasslands by considering further spatial interactions and feedbacks between plant cover and herbivore grazing. The results show that small-scale loss of plant cover promotes plant production in remaining patches due to the redistribution of water, i.e. a negative feedback between reduced plant cover and increased plant growth in remaining vegetation. But reducing vegetation cover beyond a critical threshold results in a positive feedback between reduced cover and increased grazing that can lead to the collapse of vegetation on larger scales. Thus, these kinds of ecohydrological process-based models yield significant insight into landscape dynamics together with considerable implications for the management of these landscapes by focussing on the multi-scale interactions between ecological and hydrological processes.

\section{Visions for PUB}

The task of prediction in ungauged basins (PUB) can be interpreted as a search for some general catchment transfer functions in combination with methods to assess their predictive uncertainty (Sivapalan et al., 2003b). We are seeking for a general framework to identify and represent the spatial heterogeneity in terrain, soil and vegetation properties controlling hydrological processes and to delineate the dominant patterns and processes that determine the catchment response. Of course, I do not have an answer to these questions, but a side-glance at other disciplines could suggest some analogies and ideas. The following thoughts direct into a plea for classification, which often stands at the beginning of scientific engagement and not at its cutting edge; but requesting a new classification system is not out-of-date in hydrology (Woods, 2002).

In ecology and hydrology, information is limited. Detailed information is often available at small scales or low hierarchical levels only (hillslopes, single species) but the most pressing issues occur at larger scales (i.e. the problem of scale, cf. Levin, 1992). Therefore, there is a need for upscaling and aggregation. Vegetation ecologists developed plant functional classification schemes to build models that predict the effect of climate and land use change on vegetation and to make generalisations by comparing across environments (Gitay and Noble, 1997; Lavorel et al., 1997). In such approaches, species are aggregated into functional groups considering either response traits - governing characteristic 
species response to environmental factors such as resource availability or disturbance -, or effect traits that determine the species effect on ecosystem functions (Lavorel and Garnier, 2002). The advantages of such an approach are: i) aggregation of species diversity into operational units, ii) transferability to other landscapes without necessarily having the same species set present, iii) generality, and iv) concentration on functional aspects. Classification schemes like this have successfully been used in other fields such as soil ecology (e.g. Brussaard, 1998) or riverine ecology (e.g. Merritt et al., 2002). Due to the extremely high number of species, the classification mainly refers to easy-to-measure properties ("soft" traits like e.g. mean seed number per individual). They serve as proxies for process-related "hard" traits (like e.g. intrinsic growth rates) that can hardly be measured or estimated for each species.

Distributed process-based hydrological models use functional units to represent catchments (e.g. Becker and Braun, 1999; Zehe et al., 2001). Depending on the underlying blueprint, these functional units that serve as representative elementary areas can either be hydrotopes, hydrological response units or hillslopes (Wood et al., 1988) or representative elementary watersheds (Reggiani et al., 1998). Their composition and spatial configuration strongly govern the hydrological connectivity and control the catchment response. If adequately defined, they additionally represent the spatial heterogeneity of relevant properties of soil, terrain, and vegetation. Thus, a classification of these elementary units into functional groups according to their hydrological function and specific traits may help to provide a general framework (cf. Frissell et al., 1986; Snelder and Biggs, 2002). This kind of classification can be strongly improved if sophisticated methods of pattern description are applied that can account for connectivity and configuration. As an example, graph-theoretical approaches can offer quantitative information on connectivity (Urban and Keitt, 2001). Wavelets transforms can yield integrative information regarding spatial and temporal patterns of climatological, hydrological, geomorphological, pedological, and ecological variables on a hierarchy of scales (Saunders et al., 1998; Keitt, 2000; Maraun and Kurths, 2004; Jenouvrier et al., 2005; Camarero et al., 2006). Both approaches provide information representing promising catchment traits that may serve as a basis for a general classification scheme of catchments to gain a deeper understanding of the relationship between patterns and processes in catchments and to make better predictions.

\section{Conclusions}

Landscape ecology and catchment hydrology, both disciplines deal with patterns and processes as well as their interactions and functional implications on a variety of scales. The present paper points out common concepts (such as spatial structure, scale, dominant processes, connectivity, crit- ical thresholds) and identifies common needs, i.e. a general framework for the representation of spatial heterogeneity, a theory of scaling, a standard toolbox for the analysis of spatiotemporal patterns, and interdisciplinary approaches using integrated process-based models. Selected examples demonstrate the interplay between ecological and hydrological patterns and processes and how each discipline can provide valuable information for the other. In analogy to plant functional classification schemes, I suggest classification into functional catchment groups supported by sophisticated methods of pattern description regarding multiple traits as a promising step towards finding general catchment transfer functions that may support prediction in ungauged basins.

Acknowledgements. The author would like to thank C. Harman, B. Schaefli, E. Zehe and three anonymous referees for their valuable comments and discussions on the manuscript. The development of ideas in this paper was stimulated by discussion with M. Sivapalan and E. Zehe who thankworthy invited me to the PUB initiative during the VIIth IAHS Scientific Assembly in Foz do Iguaçu, supported by the German Science Foundation (KON48/2005 SCHR1000/1-1). The research on the landscape model presented in Example I was part of the MOSAIK-Project - thanks to all co-workers - which was supported by the German Federal Ministry of Education and Research (BMBF, Grant 01LN0007).

Edited by: E. Zehe

\section{References}

Addicott, J., Aho, J., Antolin, M., Padilla, D., Richardson, J., and Soluk, D.: Ecological neighborhoods: scaling environmental patterns, Oikos, 49, 340-346, 1987.

Allen, R. G., Pereira, L. S., Raes, D., and Smith, M.: Crop evapotranspiration - Guidelines for computing crop water requirements. FAO Irrigation and drainage paper 56, Tech. Rep. M-56, FAO - Food and Agriculture Organization of the United Nations, 1998.

Amoros, C. and Bornette, G.: Connectivity and biocomplexity in waterbodies of riverine floodplains, Freshwater Biol., 47, 761776, 2002.

Austin, M.: Continuum concept, ordination methods and niche theory, Ann. Rev. Ecol. Syst., 16, 39-61, 1985.

Baird, A. J., Price, J. S., Roulet, N. T., and Heathwaite, A. L.: Special issue of Hydrological Processes Wetland Hydrology and Eco-Hydrology, Hydrol. Processes, 18, 211-212, 2004.

Bascompte, J. and Sole, R. V.: Habitat fragmentation and extinction thresholds in spatially explicit models, J. Anim. Ecol., 65, 465473, 1996.

Becker, A. and Braun, P.: Disaggregation, aggregation and spatial scaling in hydrological modelling, J. Hydrol., 217, 239-252, 1999.

Beven, K.: Towards a coherent philosophy of environmental modelling, Proc. R. Soc. Lond. A, 458, 2465-2484, 2002.

Beven, K.: A manifesto for the equifinality thesis, J. Hydrol., 320, 18-36, 2006. 
Biggs, B. J. F., Nikora, V. I., and Snelder, T. H.: Linking scales of flow variability to lotic ecosystem structure and function, River Res. Appl., 21, 283-298, 2005.

Bio, A. M., De Becker, P., De Bie, E., Huybrechts, W., and Wassen, M.: Prediction of plant species distribution in lowland river valleys in Belgium: modelling species response to site conditions, Biodiversity Conserv., 11, 2189-2216, 2002.

Blöschl, G. and Sivapalan, M.: Scale issues in hydrological modelling: a review, Hydrol. Processes, 9, 251-290, 1995.

Boer, M. and Puigdefabregas, J.: Effects of spatially structured vegetation patterns on hillslope erosion in a semiarid Mediterranean environment: a simulation study, Earth Surf, Proc. Landf., 30, 149-167, 2005.

Bolduan, R. and Zehe, E.: Abbau von Isoproturon in RegenwurmMakroporen und in der Unterbodenmatrix - Eine Feldstudie, J. Plant Nutr. Soil Sci., 169, 87-94, 2006.

Bolker, B.: Integrating ecological models and data in R, Princeton University Press, Princeton, 2006.

Bond, B.: Hydrology and ecology meet-and the meeting is good, Hydrol. Processes, 17, 2087-2089, 2003.

Bonn, A. and Schröder, B.: Habitat models and their transfer for single- and multi-species groups: a case study of carabids in an alluvial forest, Ecography, 24, 483-496, 2001.

Bornette, G. and Amoros, C.: Disturbance regimes and vegetation dynamics: role of floods in riverine wetlands, J. Veg. Sci., 7, 615-622, 1996.

Brussaard, L.: Soil fauna, guilds, functional groups and ecosystem processes, Appl. Soil Ecol., 9, 123-135, 1998.

Burt, T. P. and Pinay, G.: Linking hydrology and biogeochemistry in complex landscapes, Progr. Phys. Geogr., 29, 297-316, 2005.

Camarero, J. J., Gutiérrez, E., and Fortin, M.-J.: Spatial patterns of plant richness across treeline ecotones in the Pyrenees reveal different locations for richness and tree cover boundaries, Global Ecol. Biogeogr., 15, 182-191, 2006.

Cammeraat, E. L. H.: Scale dependent thresholds in hydrological and erosion response of a semi-arid catchment in southeast Spain, Agricult. Ecosys. Environ., 104, 317-332, 2004.

Cammeraat, L. and Imeson, A. C.: The evolution and significance of soil-vegetation patterns following land abandonment and fire in Spain, Catena, 37, 107-127, 1999.

Cantwell, M. D. and Forman, R. T.: Landscape graphs: Ecological modeling with graph theory to detect configurations common to diverse landscapes, Landscape Ecol., 8, 239-255, 1993.

Chesson, P., Gebauer, R. L. E., Schwinning, S., Huntly, N., Wiegand, K., Ernest, M. S. K., Sher, A., Novoplansky, A., and Weltzin, J. F.: Resource pulses, species interactions, and diversity maintenance in arid and semi-arid environments, Oecologia, 141, 236-253, 2004.

Cottenie, K. and De Meester, L.: Connectivity and cladoceran species richness in a metacommunity of shallow lakes, Freshwater Biol., 48, 823-832, 2003.

Covich, A. P., Austen, M. C., Bärlocher, F., Chauvet, E., Cardinale, B. J., Biles, C. L., Inchausti, P., Dangles, O., Solan, M., Gessner, M. O., Statzner, B., and Moss, B.: The role of biodiversity in the functioning of freshwater and marine benthic ecosystems, BioScience, 54, 767-775, 2004.

De Swart, E., van der Valk, A., Koehler, K., and Barendregt, A.: Experimental evaluation of realized niche models for predicting responses of plant species to a change in environmental condi- tions, J. Veg. Sci., 5, 541-552, 1994.

Decaëns, T. and Rossi, J. P.: Spatio-temporal structure of earthworm community and soil heterogeneity in a tropical pasture, Ecography, 24, 671-682, 2001.

Delcourt, H. R. and Delcourt, P. A.: Quaternary landscape ecology: relevant scales in space and time, Landscape Ecol., 2, 23-44, 1988.

Diaz, S., Cabido, M., and Casanoves, F.: Plant functional traits and environmental filters at a regional scale, J. Veg. Sci., 9, 113-122, 1998.

Diekmann, M.: Species indicator values as an important tool in applied plant ecology: a review, Basic Appl. Ecol., 4, 493-506, 2003.

Dodds, P. S. and Rothman, D. H.: Scaling, universality, and geomorphology, Ann. Rev. Earth Planet. Sci., 28, 571-610, 2000.

Dominguez, J., Bohlen, P. J., and Parmelee, R. W.: Earthworms increase nitrogen leaching to greater soil depths in row crop agroecosystems, Ecosystems, 7, 672-685, 2004.

DVWK (Ed.): Ermittlung der Verdunstung von Land- und Wasserflächen, vol. 238, Wirtschafts- und Verlagsgesellschaft Gas und Wasser mbH, Bonn, 1996.

Edwards, W., Shipitalo, M., Owens, L., and Norton, L.: Water and nitrate movement in earthworm burrows within long-term no- till cornfields, J. Soil Water Conserv., 44, 240-243, 1989.

Ehleringer, J. R., Phillips, S. L., Schuster, W. S. F., and Sandquist, D. R.: Differential utilization of summer rains by desert plants, Oecologia, 88, 430-434, 1991.

Ellenberg, H.: Vegetation ecology of Central Europe, Cambridge University Press, Cambridge, 4th ed. edn., 1988.

Ellenberg, H., Weber, H.-E., Düll, R., Wirth, V., Werner, W., and Paulissen, D.: Zeigerwerte von Pflanzen in Mitteleuropa, vol. 18, Goltze, Göttingen, 2nd edn., 1992.

Ertsen, A., Alkemade, J., and Wassen, M.: Calibrating Ellenberg indicator values for moisture, acidity, nutrient availability and salinity in the Netherlands, Plant Ecol., 135, 113-124, 1998.

Fortin, M.-J. and Dale, M. R.: Spatial analysis - a guide for ecologists, Cambridge University Press, Cambridge, 1st edn., 2005.

Frissell, C. A., Liss, W., Warren, C., and Hurley, M.: A hierarchical framework for stream habitat classification: viewing streams in a watershed context, Environ. Manage., 10, 199-214, 1986.

Gardner, R. H., Milne, B. T., Turner, M. G., and O'Neill, R. V.: Neutral models for the analysis of broad-scale landscape pattern, Landscape Ecol., 1, 19-28, 1987.

Gitay, H. and Noble, I. R.: What are functional types and how should we seek them?, in: Plant functional types: Their relevance to ecosystem properties and global change, edited by: Smith, T. M., Shugart, H. H., and Woodward, F. I., pp. 3-19, Cambridge University Press, Cambridge, 1997.

Grayson, R. and Blöschl, G.: Spatial processes, organisation and patterns, in: Spatial patterns in catchment hydrology, edited by: Grayson, R. and Blöschl, G., pp. 3-16, Cambridge University Press, Cambridge, 2000a.

Grayson, R. and Blöschl, G.: Summary of pattern comparison and concluding remarks, in: Spatial patterns in catchment hydrology, edited by: Grayson, R. and Blöschl, G., pp. 355-367, Cambridge University Press, Cambridge, 2000b.

Grayson, R. B., Western, A., Chiew, F., and Blöschl, G.: Preferred states in spatial soil moisture patterns: Local and nonlocal controls, Water Resour. Res., 33, 2897-2908., 1997. 
Grimm, V., Revilla, E., Berger, U., Jeltsch, F., Mooij, W. M., Railsback, S., Thulke, H.-H., Weiner, J., Wiegand, T., and DeAngelis, D. L.: Pattern-oriented modeling of agent-based complex systems: lessons from ecology, Science, 310, 987-991, 2005.

Groffman, P., Baron, J. S., Blett, T., Gold, A. J., Goodman, I., Gunderson, L. H., Levinson, B. M., Palmer, M. A., Paerl, H. W., Peterson, G. D., Poff, N. L., Rejeski, D. W., Reynolds, J. F., Turner, M. G., Weathers, K. C., and Wiens, J.: Ecological thresholds: the key to successful environmental management or an important concept with no practical application?, Ecosystems, 9, 1-13, 2006.

Guisan, A. and Thuiller, W.: Predicting species distribution: offering more than simple habitat models, Ecol. Lett., 8, 993-1009, 2005.

Guisan, A. and Zimmermann, N. E.: Predictive habitat distribution models in ecology, Ecol. Model., 135, 147-186, 2000.

Gurnell, A. M., Hupp, C. R., and Gregory, S. V.: Linking hydrology and ecology, Hydrol. Proc., 14, 2813-2815, 2000.

Gurnell, A. M., Petts, G. E., Hannah, D. M., Smith, B., Edwards, P. J., Kollmann, J., Ward, J. V., and Tockner, K.: Riparian vegetation and island formation along the gravel-bed Fiume Tagliamento, Italy, Earth Surf. Proc. Landf., 26, 31-62, 2001.

Gustafson, E. J.: Quantifying landscape spatial pattern: what is the state of the art?, Ecosystems, 1, 143-156, 1998.

Hannah, D. M., Wood, P. J., and Sadler, J. P.: Ecohydrology and hydroecology: A new paradigm?, Hydrol. Processes, 18, 34393445, 2004.

Hanski, I. A. and Gilpin, M., eds.: Metapopulation biology: ecology, genetics, and evolution, Academic Press, San Diego, 1997.

Harrell, F. E. J.: Regression modeling strategies: with applications to linear models, logistic regression, and survival analysis, Springer, New York, 2001.

Hill, M. O., Roy, D. B., Mountford, J. O., and Bunce, R. G.: Extending Ellenberg's indicator values to a new area: an algorithmic approach, J. Appl. Ecol., 37, 3-15, 2000.

HilleRisLambers, R., Rietkerk, M., van den Bosch, F., Prins, H., and de Kroon, H.: Vegetation pattern formation in semi-arid grazing systems, Ecology, 82, 50-61, 2001.

Holling, C. S. and Allen, C. R.: Adaptive inference for distinguishing credible from incredible patterns in nature, Ecosystems, 5, 319-328, 2002.

Hutchinson, G. E.: Concluding remarks, Cold Spring Harbor Symposium on Quantitative Biology, 22, 415-427, 1957.

Huxman, T. E., Wilcox, B. P., Breshears, D. D., Scott, R. L., Snyder, K. A., Small, E. E., Hultine, K., Pockman, W. T., and Jackson, R. B.: Ecohydrological implications of woody plant encroachment, Ecology, 86, 308-319, 2005.

Imeson, A. C. and Prinsen, H. A. M.: Vegetation patterns as biological indicators for identifying runoff and sediment source and sink areas for semi-arid landscapes in Spain, Agric, Ecosys. Environ., 104, 333-342, 2004.

Jax, K.: Function and "functioning" in ecology: what does it mean?, Oikos, 111, 641-648, 2005.

Jeltsch, F., Moloney, K., and Milton, S. J.: Detecting process from snapshot pattern: lessons from tree spacing in the southern Kalahari, Oikos, 85, 451-466, 1999.

Jenouvrier, S., Barbraud, C., Cazelles, B., and Weimerskirch, H.: Modelling population dynamics of seabirds: importance of the effects of climate fluctuations on breeding proportions, Oikos,
108, 511-522, 2005.

Jimenez, J., Rossi, J.-P., and Lavelle, P.: Spatial distribution of earthworms in acid-soil savannas of the eastern plains of Colombia, Appl. Soil Ecol., 17, 267-278, 2001.

Jones, C. G., Lawton, J. H., and Shachak, M.: Organisms as ecosystem engineers, Oikos, 69, 373-386, 1994.

Jouquet, P., Dauber, J., Lagerlöf, J., Lavelle, P., and Lepage, M.: Soil invertebrates as ecosystem engineers: Intended and accidental effects on soil and feedback loops, Appl. Soil Ecol., 32, 153-164, 2006.

Kareiva, P.: Space - the final frontier for ecological theory, Ecology, 75, 1, 1994.

Keddy, P.: Assembly and response rules: two goals for predictive community ecology, J. Veg. Sci., 3, 157-164, 1992.

Keitt, T. H.: Spectral representation of neutral landscapes, Landscape Ecol., 15, 479-493, 2000.

Keitt, T. H. and Urban, D.: Scale-specific inference using wavelets, Ecology, 86, 2497-2504, 2005.

Keitt, T. H., Urban, D. L., and Milne, B. T.: Detecting critical scales in fragmented landscapes, Conserv. Ecol., 1, http: //www.consecol.org/vol1/iss1/art4, 1997.

Keymer, J. E., Marquet, P. A., Velasco-Hernandez, J. X., and Levin, S. A.: Extinction thresholds and metapopulation persistence in dynamic landscapes, Am. Nat., 156, 478-494, 2000.

Klemes, V.: Conceptualization and scale in hydrology, J. Hydrol., 65, 1-23, 1983.

Laio, F., Porporato, A., Fernandez-Illescas, C., and RodriguezIturbe, L.: Plants in water-controlled ecosystems: active role in hydrologic processes and response to water stress - IV. Discussion of real cases, Adv. Water Res., 24, 745-762, $2001 \mathrm{a}$.

Laio, F., Porporato, A., Ridolfi, L., and Rodriguez-Iturbe, I.: Plants in water-controlled ecosystems: active role in hydrologic processes and response to water stress - II. Probabilistic soil moisture dynamics, Adv. Water Res., 24, 707-723, $2001 \mathrm{~b}$.

Latterell, J. J., Bechtold, J. S., O'Keefe, T. C., Van Pelt, R., and Naiman, R. J.: Dynamic patch mosaics and channel movement in an unconfined river valley of the Olympic Mountains, Freshw. Biol., 51, 523-544, 2006.

Lavelle, P., Bignell, D., Lepage, M., Wolters, V., Roger, P., Ineson, P., Heal, O., and Dhillion, S.: Soil function in a changing world: the role of invertebrate ecosystem engineers, Eur. J. Soil Biol., 33, 159-193, 1997.

Lavorel, S. and Garnier, E.: Predicting changes in community composition and ecosystem functioning from plant traits: revisiting the Holy Grail, Funct. Ecol., 16, 545-556, 2002.

Lavorel, S., McIntyre, S., Landsberg, J., and Forbes, T.: Plant functional classifications: from general groups to specific groups based on response to disturbance, Trends Ecol. Evol., 12, 474478, 1997.

Le Bayon, R. and Binet, F.: Earthworms change the distribution and availability of phosphorous in organic substrates, Soil Biol Biochem., 38, 235-246, 2006.

Levin, S. A.: The problem of pattern and scale in ecology, Ecology, 73, 1943-1967, 1992.

Levin, S. A.: Ecosystems and the biosphere as complex adaptive systems, Ecosystems, 1, 431-436, 1998.

Leyer, I.: Predicting plant species' responses to river regulation: the role of water level fluctuations, J. Appl. Ecol., 42, 239-250, 2005. 
Lischke, H.: Modeling tree species migration in the Alps during the Holocene: What creates complexity?, Ecol. Complex., 2, 159174, 2005.

Loik, M. E., Breshears, D. D., Lauenroth, W. K., and Belnap, J.: A multi-scale perspective of water pulses in dryland ecosystems: climatology and ecohydrology of the western USA, Oecologia, 141, 269-281, 2004.

Lookingbill, T. R., Goldenberg, N. E., and Williams, B. H.: Understorey species as soil moisture indicators in Oregon's Western Cascadesold-growth forests, Northwest Science, 78, 214-224, 2004.

Ludwig, J. A., Wilcox, B. P., Breshears, D. D., Tongway, D. J., and Imeson, A. C.: Vegetation patches and runoff-erosion as interacting ecohydrological processes in semiarid landscapes, Ecology, 86, 288-297, 2005.

Lytle, D. and Poff, N.: Adaptation to natural flow regimes, Trends Ecol. Evol., 19, 94-100, 2004.

MacArthur, R. and Wilson, E.: The theory of island biogeography, Princeton Univ. Press, Princeton, 1967.

Mackey, B. G. and Lindenmayer, D. B.: Towards a hierarchical framework for modelling the spatial distribution of animals, J. Biogeogr., 28, 1147-1166, 2001.

Malard, F., Tockner, K., and Ward, J.: Shifting dominance of subcatchment water sources and flow paths in a glacial floodplain, Val Roseg, Switzerland., Arctic Antarct. Alp. Res., 31, 135-150, 1999.

Maraun, D. and Kurths, J.: Cross wavelet analysis. significance testing and pitfalls, Nonlin. Processes Geophys., 11, 505-514, 2004, http://www.nonlin-processes-geophys.net/11/505/2004/.

May, R. M.: Thresholds and breakpoints in ecosystems with a multiplicity of stable states, Nature, 269, 471-477, 1977.

Merritt, R. W., Cummins, K. W., Berg, M. B., Novak, J. A., Higgins, M. J., Wessell, K. J., and Lessard, J. L.: Development and application of a macroinvertebrate functional-group approach in the bioassessment of remnant river oxbows in southwest Florida, J. N. Am. Benthol. Soc., 21, 290-310, 2002.

Milcu, A., Schumacher, J., and Scheu, S.: Earthworms (Lumbricus terrestris) affect plant seedling recruitment and microhabitat heterogeneity, Funct. Ecol., 20, 261-268, 2006.

Milne, A. E., Lark, R. M., Addiscott, T. M., Goulding, K. W. T., Webster, C. P., and O'Flaherty, S.: Wavelet analysis of the scale and location dependent correlation of modelled and measured nitrous oxide emissions from soil, Eur. J. Soil Sci., 56, 3-17, 2005.

Milne, B., Gupta, V., and Restrepo, C.: A scale invariant coupling of plants, water, energy, and terrain, Ecoscience, 9, 191-199, 2002.

Naiman, R., Johnston, C., and Kelley, J.: Alteration of North American streams by beaver, BioScience, 38, 753-762, 1988.

Naiman, R. J. and Decamps, H.: The ecology of interfaces: riparian zones, Ann. Rev. Ecol. Syst., 28, 621-658, 1997.

Ocampo, C. J., Sivapalan, M., and Oldham, C.: Hydrological connectivity of upland-riparian zones in agricultural catchments: Implications for runoff generation and nitrate transport, J. Hydrol., 331, 643-658, 2006.

Olde Veterink, H. and Wassen, M.: A comparison of six models predicting vegetation response to hydrological hybitat change, Ecol. Model., 101, 347-361, 1997.

Olff, H., Vera, F., Bokdam, J., Bakker, E., Gleichman, J., de Maeyer, K., and Smit, R.: Shifting mosaics in grazed woodlands driven by the alternation of plant facilitation and competition, Plant Biol.,
1, 127-137, 1999.

O’Neill, R. V., Krummel, J., Gardner, R., Sugihara, G., Jackson, B., DeAngelis, D., Milne, B., Turner, M. G., Zygmunt, B., Christensen, S., Dale, V., and Graham, R.: Indices of landscape patterns, Landscape Ecol., 1, 153-162, 1988.

Ovaskainen, O., Sato, K., Bascompte, J., and Hanski, I.: Metapopulation models for extinction threshold in spatially correlated landscapes, J. Theor. Biol., 215, 95-108, 2002.

Parrott, L.: Quantifying the complexity of simulated spatiotemporal population dynamics, Ecol. Complex., 2, 175-184, 2005.

Peck, S.: Simulation as experiment: a philosophical reassessment for biological modeling, Trends Ecol. Evol., 19, 530-534, 2004.

Peppler-Lisbach, C. and Schröder, B.: Predicting the species composition of mat-grass communities (Nardetalia) by logistic regression modelling, J. Veg. Sci., 15, 623-634, 2004.

Poff, N.: Landscape filters and species traits: towards mechanistic understanding and prediction in stream ecology, J. N. Am. Benthol. Soc., 16, 391-409, 1997.

Poole, G., Stanford, J. A., Running, S. W., Frissell, C. A., Woessner, W., and Ellis, B.: A patch hierarchy approach to modeling surface and sub-surface hydrology in complex flood-plain environments, Earth Surf. Proc. Landf., 29, 1259-1274, 2004.

Poole, G. C.: Fluvial landscape ecology: addressing uniqueness within the river discontinuum, Freshwater Biol., 47, 641-660, 2002.

Porporato, A., Laio, F., Ridolfi, L., and Rodriguez-Iturbe, I.: Plants in water-controlled ecosystems: active role in hydrologic processes and response to water stress - III. Vegetation water stress, Adv. Water Res., 24, 725-744, 2001.

Pringle, C.: What is hydrologic connectivity and why is it ecologically important?, Hydrol. Processes, 17, 2685-2689, 2003.

Puigdefabregas, J.: The role of vegetation patterns in structuring runoff and sediment fluxes in drylands, Earth Surf, Proc. Landf., 30, 133-147, 2005.

Reggiani, P. and Schellekens, J.: Modelling of hydrological responses: the representative elementary watershed approach as an alternative blueprint for watershed modelling, Hydrol. Processes, 17, 3785-3789, 2003.

Reggiani, P., Hassanizadeh, S. M., and Sivapalan, M.: A unifying framework for watershed thermodynamics: balance equations for mass, momentum, energy and entropy, and the second law of thermodynamics, Adv. Water Res., 22, 367-398, 1998.

Remmel, T. K. and Csillag, F.: When are two landscape indexes significantly different?, J. Geograph. Syst., 5, 331-351, 2003.

Remmert, H. (Ed.): The mosaic-cycle concept in ecosystems, Springer, Berlin, 1. edn., 1991.

Reynolds, J. and Wu, J.: Do landscape structural and functional units exist?, in: Integrating hydrology, ecosystem dynamics, and biogeochemistry in complex landscapes, edited by: Tenhunen, J. D. and Kabat, P., pp. 273-296, John Wiley, Chichester, 1999.

Rietkerk, M. and van de Koppel, J.: Alternate stable states and threshold effects in semi-arid grazing systems, Oikos, 79, 69-76, 1997.

Rietkerk, M., Boerlijst, M. C., van Langevelde, F., HilleRisLambers, R., van de Koppel, J., Kumar, L., Prins, H. H. T., and de Roos, A. M.: Self-organization of vegetation in arid ecosystems, Am. Nat., 160, 524-530, 2002.

Rietkerk, M., Dekker, S., Wassen, M., Verkroost, A., and Bierkens, M.: A putative mechanism for bog patterning, Am. Nat., 163, 
699-708, 2004a.

Rietkerk, M., Dekker, S. C., de Ruiter, P. C., and van de Koppel, J.: Self-organized patchiness and catastrophic shifts in ecosystems, Science, 305, 1926-1929, 2004b.

Ritchie, M. E. and Olff, H.: Spatial scaling laws yield a synthetic theory of biodiversity, Nature, 400, 557-560, 1999.

Robinson, C. T., Tockner, K., and Ward, J. V.: The fauna of dynamic riverine landscapes, Freshw. Biol., 47, 661-678, 2002.

Rodriguez-Iturbe, I. and Porporato, A.: Ecohydrology of watercontrolled ecosystems, Cambridge University Press, Cambridge, 2004.

Rodriguez-Iturbe, I., Porporato, A., Laio, F., and Ridolfi, L.: Plants in water-controlled ecosystems: active role in hydrologic processes and response to water stress - I. Scope and general outline, Adv. Water Res., 24, 697-705, 2001.

Rosales, J., Petts, G., and Knab-Vispo, C.: Ecological gradients within the riparian forests of the lower Caura River, Venezuela, Plant Ecol., 152, 101-118, 2001.

Rudner, M., Biedermann, R., Schröder, B., and Kleyer, M.: Integrated grid based ecological and economic (INGRID) landscape model - a tool to support landscape management decisions, Environ. Model. Softw., 22, 177-187, 2007.

Saunders, S. C., Chen, J., Crow, T. R., and Brosofske, K. D.: Hierarchical relationships between landscape structure and temperature in a managed forest landscape, Landscape Ecol., 13, 381-395, 1998.

Schaffers, A. and Sykora, K.: Reliability of Ellenberg indicator values for moisture, nitrogen and soil reaction: a comparison with field measurements, J. Veg. Sci., 11, 225-244, 2000.

Schmidtlein, S.: Imaging spectroscopy as a tool for mapping Ellenberg indicator values, J. Appl. Ecol., 42, 966-974, 2005.

Schröder, B. and Seppelt, R.: Analysis of pattern-processinteractions based on landscape models - overview, general concepts, methodological issues, Ecol. Model., 199, 505-516, 2006.

Schröder, B., Rudner, M., Biedermann, R., and Kleyer, M.: Ökologische und sozio-ökonomische Bewertung von Managementsystemen fr die Offenhaltung von Landschaften - ein integriertes Landschaftsmodell, UFZ-Bericht, 9/2004, 121-132, 2004

Schulz, K., Seppelt, R., Zehe, E., Vogel, H., and Attinger, S.: The importance of structure and its dynamics in advancing hydrological sciences, Water Res. Res., 42, W03S03, doi:10.1029/2005WR004301, 2006.

Schwinning, S. and Sala, O. E.: Hierarchy of responses to resource pulses in arid and semi-arid ecosystems, Oecologia, 141, 211220, 2004

Schwinning, S., Sala, O. E., Loik, M. E., and Ehleringer, J. R.: Thresholds, memory, and seasonality: understanding pulse dynamics in arid/semi-arid ecosystems, Oecologia, 141, 191-193, 2004.

Shipitalo, M., Dick, W., and Edwards, W.: Conservation tillage and macropore factors that affect water movement and the fate of chemicals, Soil Till. Res., 53, 167-183, 2000.

Shipitalo, M. J. and Butt, K. R.: Occupancy and geometrical properties of Lumbricus terrestris L. burrows affecting infiltration, Pedobiologia, 43, 782-794, 1999.

Silvertown, J., Dodd, M., Gowing, D., and Mountford, J.: Hydrologically defined niches reveal a basis for species richness in plant communities, Nature, 400, 61-63, 1999.
Sivapalan, M.: Process complexity at hillslope scale, process simplicity at the watershed scale: is there a connection?, Hydrol. Processes, 17, 1037-1041, 2003.

Sivapalan, M.: Pattern, process and function: elements of a unified theory of hydrology at the catchment scale, Encyclop. Hydrol. Sci., 2005.

Sivapalan, M., Blöschl, G., Zhang, L., and Vertessy, R.: Downward approach to hydrological prediction, Hydrol. Processes, 17, 2101-2111, 2003a.

Sivapalan, M., Takeuchi, K., Franks, S. W., Gupta, V. K., Karambiri, H., Lakshmi, V., Liang, X., McDonnell, J. J., Mendiondo, E. M., OConnell, P. E., Oki, T., Pomeroy, J. W., Schertzer, D., Uhlenbrook, S., and Zehe, E.: IAHS decade on predictions in ungauged basins (PUB), 2003-2012: Shaping an exciting future for the hydrological sciences, Hydrol. Sci. J., 48, 857-880, 2003b.

Smettem, K. R. J.: The relation of earthworms to soil hydraulic properties, Soil Biol. Biochem., 24, 1539-1543, 1992.

Snelder, T. H. and Biggs, B. J. F.: Multiscale river environment classification for water resources management, J. Am. Water Res. Assoc., 38, 1225-1239, 2002.

Söndgerath, D. and Schröder, B.: Population dynamics and habitat connectivity affecting spatial spread of populations - a simulation study, Landscape Ecol., 17, 57-70, 2002.

Southwood, T. R. E., May, R. M., and Sugihara, G.: Observations on related ecological exponents, PNAS, 103, 6931-6933, 2006.

Stanford, J. A.: Rivers in the landscape: introduction to the special issue on riparian and groundwater ecology, Freshw. Biol., 40, 402-406, 1998.

Statzner, B., Doledec, S., and Hugueny, B.: Biological trait composition of European stream invertebrate communities: assessing the effects of various trait filter types, Ecography, 27, 470-488, 2004.

Stauffer, D. and Aharony, A.: Introduction to percolation theory, Taylor and Francis, London, 2nd edn., 1991.

Tabacchi, E., Correll, D. L., Hauer, R., Pinay, G., Planty-Tabacchi, A.-M., and Wissmar, R. C.: Development, maintenance and role of riparian vegetation in the river landscape, Freshwater Biol., 40, 497-516, 1998.

Tabacchi, E., Lambs, L., Guilloy, H., Planty-Tabacchi, A.-M., Muller, E., and Decamps, H.: Impacts of riparian vegetation on hydrological processes, Hydrol. Processes, 14, 2959-2976, 2000.

Tietjen, B. and Jeltsch, F.: Semi-arid grazing systems and climate change - a survey of present modelling potential and future needs, J. Appl. Ecol., in press, 2006.

Tockner, K., Ward, J. V., Edwards, P. J., and Kollmann, J.: Riverine landscapes: an introduction, Freshwater Biol., 47, 497-500, 2002.

Turner, M. G.: Landscape ecology: the effect of pattern on process, Ann. Rev. Ecol. Syst., 20, 171-197, 1989.

Turner, M. G.: Landscape ecology in North America: past, present, and future, Ecology, 86, 1967-1974, 2005a.

Turner, M. G.: Landscape ecology: what is the state of the science?, Ann. Rev. Ecol. System., 36, 319-344, 2005b.

Turner, M. G., Gardner, R. H., and O’Neill, R. V.: Landscape ecology in theory and practice - pattern and process, Springer, New York, 2001.

Urban, D. and Keitt, T.: Landscape connectivity: a graph-theoretic perspective, Ecology, 82, 1205-1218, 2001. 
Urban, D. L.: Modeling ecological processes across scales, Ecology, 86, 1996-2006, 2005.

Urban, D. L., O'Neill, R., and Shugart, H. H. J.: Landscape ecology: a hierarchical perspective can help scientists understand spatial patterns., BioScience, 37, 119-127, 1987.

Valentin, C., dHerbes, J. M., and Poesen, J.: Soil and water components of banded vegetation patterns, Catena, 37, 1-24, 1999.

van de Koppel, J. and Rietkerk, M.: Spatial interactions and resilience in arid ecosystems, Am. Nat., 163, 113-121, 2004.

van de Koppel, J., Rietkerk, M., van Langevelde, F., Kumar, L., Klausmeier, C. A., Fryxell, J. M., Hearne, J. W., van Andel, J., de Ridder, N., Skidmore, A., Stroosnijder, L., and Prins, H. H. T.: Spatial heterogeneity and irreversible vegetation change in semiarid grazing systems, Am. Nat., 159, 209-219, 2002.

Vereecken, H.: Estimating the unsaturated hydraulic conductivity from theoretical models using simple soil properties, Geoderma, 65, 81-92, 1995.

Vogel, H. J. and Roth, K.: Moving through scales of flow and transport in soil, J. Hydrol., 272, 95-106, 2003.

Wagner, H. H. and Fortin, M.-J.: Spatial analysis of landscapes: concepts and statistics, Ecology, 86, 1975-1987, 2005.

Waldenmeyer, G.: Abflussbildung und Regionalisierung in einem forstlich genutzten Einzugsgebiet (Dürreychtal, Nordschwarzwald), Phd-thesis, Universität Karlsruhe, 2002.

Ward, J. and Tockner, K.: Biodiversity: towards a unifying theme for river ecology, Freshwater Biol., 46, 807-819, 2001.

Ward, J., Malard, F., and Tockner, K.: Landscape ecology: a framework for integrating pattern and process in river corridors, Landscape Ecol., 17, 35-45, 2002a.

Ward, J. V., Tockner, K., Arscott, D. B., and Claret, C.: Riverine landscape diversity, Freshwater Biol., 47, 517-540, 2002b.

Wassen, M. and Grootjans, A.: Ecohydrology: an interdisciplinary approach for wetland management and restoration, Vegetatio, 126, 1-4, 1996.

Watt, A.: Pattern and process in the plant community, J. Ecol., 35, $1-22,1947$.

Weigel, B. M., Wang, L., Rasmussen, P. W., Butcher, J. T., Stewart, P. M., Simon, T. P., and Wiley, M. J.: Relative influence of variables at multiple spatial scales on stream macroinvertebrates in the Northern Lakes and Forest ecoregion, U.S.A., Freshwater Biol., 48, 1440-1461, 2003.

Weiler, M. and McDonnell, J.: Virtual experiments: a new approach for improving process conceptualization in hillslope hydrology, J. Hydrol., 285, 3-18, 2004.

Western, A., Blöschl, G., and Grayson, R. B.: Toward capturing hydrologically significant connectivity in spatial patterns, Water Res. Res., 37, 83-98, 2001.

Western, A. W., Grayson, R. B., and Blöschl, G.: Scaling of soil moisture: a hydrologic perspective, Ann. Rev. Earth Planet. Sci., 30, 149-180, 2002.

Wharton, G., Cotton, J. A., Wotton, R. S., Bass, J. A., Heppell, C. M., Trimmer, M., Sanders, I. A., and Warren, L. L.: Macrophytes and suspension-feeding invertebrates modify flows and fine sediments in the Frome and Piddle catchments, Dorset (UK), J. Hydrol., 330, 171-184, 2006.

Wiegand, T., Revilla, E., and Knauer, F.: Dealing with uncertainty in spatially explicit population models, Biodiversity Conserv., 13, 53-78, 2004.

Wiens, J.: Riverine landscapes: Taking landscape ecology into the water, Freshwater Biol., 47, 501-516, 2002a.

Wiens, J.: Central concepts and issues of landscape ecology, in: Applying landscape ecology in biological conservation, edited by: Gutzwiller, K. J., Springer, New York, 2002b.

Wiens, J. A.: The science and practice of landscape ecology, in: Landscape ecological analysis: issues and applications, edited by: Klopatek, J. M. and Gardner, R. H., pp. 371-384, Springer, New York, 1999.

Wiens, J. A., Stenseth, N. C., Van Horne, B., and Ims, R. A.: Ecological mechanisms and landscape ecology, Oikos, 66, 369-380, 1993.

Wierda, A., Fresco, L., Grootjans, A., and van Diggelen, R.: Numerical assessment of plant species as indicators of the groundwater regime, J. Veg. Sci., 8, 707-716, 1997.

Wilcox, B. P. and Newman, B. D.: Ecohydrology of semiarid landscapes, Ecology, 86, 275-276, 2005.

Wilcox, B. P., Breshears, D. D., and Allen, C. D.: Ecohydrology of a resource-conserving semiarid woodland: temporal and spatial scaling and disturbance, Ecol. Monogr., 73, 223-239, 2003.

Williams, D. G., Scott, R. L., Huxman, T. E., Goodrich, D. C., and Lin, G.: Sensitivity of riparian ecosystems in arid and semiarid environments to moisture pulses, Hydrol. Processes, 20, 31913205, 2006.

Wilson, D. J., Western, A. W., and Grayson, R. B.: A terrain and data-based method for generating the spatial distribution of soil moisture, Adv. Water Res., 28, 43-54, 2005.

With, K. A. and Crist, T. O.: Critical thresholds in species' responses to landscape structure, Ecology, 76, 2446-2459, 1995.

With, K. A., Gardner, R. H., and Turner, M. G.: Landscape connectivity and population distributions in heterogeneous environments, Oikos, 78, 151-169, 1997.

Wood, E. F., Sivapalan, M., Beven, K., and Band, L.: Effects of spatial variability and scale with implications to hydrologic modeling, J. Hydrol., 102, 29-47, 1988.

Woods, R.: Seeing catchments with new eyes, Hydrol. Proc., 16, 1111-1113, 2002.

Wright, J. P., Jones, C. G., and Flecker, A. S.: An ecosystem engineer, the beaver, increases species richness at the landscape scale, Oecologia, 132, 96-101, 2002.

Wu, J.: Hierarchy and scaling: Extrapolating information along a scaling ladder, Can. J. Rem. Sens., 25, 367-380, 1999.

Wu, J. and Levin, S. A.: A patch-based spatial modeling approach: conceptual framework and simulation scheme, Ecol. Model. 101, 325-346, 1997.

Zalewski, M.: Ecohydrology - the scientific background to use ecosystem properties as management tools toward sustainability of water resources, Ecol. Econ., 16, 1-8, 2002.

Zehe, E. and Flühler, H.: Slope scale distribution of flow patterns in soil profiles, J. Hydrol., 247, 116-132, 2001.

Zehe, E., Maurer, T., Ihringer, J., and Plate, E.: Modelling water flow and mass transport in a Loess catchment, Phys. Chem. Earth B, 26, 487-507, 2001.

Zehe, E., Becker, R., Bardossy, A., and Plate, E.: Uncertainty of simulated catchment runoff response in the presence of threshold processes: Role of initial soil moisture and precipitation, J. Hydrol., 315, 183-202, 2005.

Zinko, U., Seibert, J., Dynesius, M., and Nilsson, C.: Plant species numbers predicted by a topography-based groundwater flow index, Ecosystems, 8, 430-441, 2005. 